\title{
NOTA BIBLIOGRAFICA
}

\section{FRANCO, Sérgio da Costa. Porto Alegre e seu co- mércio. Porto Alegre, Associação Comercial de Porto Alegre, 1983. 191 p.}

\section{Wilson Sander*}

Este livro do conhecido escritor Sérgio da Costa Franco, reconhecido pela sua presença diária durante longo tempo no jornal Correio do Povo e não menos por sua preocupação em estudar o político Júlio de Castilhos, está sendo disputado por estudantes e professores da História do Rio Grande do Sul. Trata-se de uma edição comemorativa ao 125 ? aniversário de fundação da Associação Comercial de Porto Alegre.

O comércio pode ser considerado o trabalho humano dedicado a troca de produtos e que ao longo dos tempos foi se institucionalizando como meio de obtenção de bens que não podem ser obtidos dentro da economia local.

Jacques Le Goff e Pierre Nora já disseram que "o que força a História a se redefinir é a tomada de consciência por parte dos historiadores do relativismo de sua ciência". A História não é exclusiva dos historiadores. Hoje não tratamos apenas da políti$\mathrm{ca}$, mas de tudo que diz respeito à vida do homem.

$\mathrm{O}$ autor, porém, não se detém nas questões metodológicas. $\mathrm{O}$ texto é objetivo e sem preconceitos ideológicos. $\mathrm{Na}$ apresentação, destaca o autor o seu desejo em contribuir para a História Econômica do Rio Grande do Sul, para tal, utilizou-se do arquivo da Associação para escrever o texto. O livro oferece uma visão global da atuação do empresariado gaúcho desde 1858. Já nas primeiras páginas, diz o autor: "Porto Alegre nasceu marcada pelo destino de ser um entreposto comercial" (p.9). De fato, no Rio Grande 
do Sul e como tal também em Porto Alegre, o comércio e a manufatura tiveram um desenvolvimento considerável. Mesmo assim, nunca conseguiram impor-se como forma produtiva e de peso na economia. A dependência ao campo nunca foi superada. Porto Alegre sempre foi mais centro de consumo do que de produção.

Interessante e curiosa a referência encontrada na página 55 sob o título "A Guerra do Paraguai deu bons negócios": "Durante o conflito, o Arsenal de Guerra, aqui funcionando, teve uma expressiva ampliação de suas atividades. Mantendo oficinas de coronheiros, de ferreiros e armeiros, de corrieiros e de alfaiates, de latoeiros e funileiros, foi aquele estabelecimento militar a primeira grande fábrica de Porto Alegre, chegando a empregar, nos primeiros meses de 1867, mais de duzentos trabalhadores, não se contando os menores aprendizes, que eram várias dezenas, e alguns prisioneiros paraguaios também eventualmente vitilizados no serviço".

Com relação às inovações tecnológicas e suas repercussões, chama a atenção do leitor o capítulo referente ao papel das ferrovias na vida econômica do Estado (p. 107), onde o autor afirma: "Na fronteira oeste, uma ferrovia, também inglesa, ligou Barra do Quaraí a Uruguaiana (1887) e Itaqui (1888), sem conexão alguma com o restante do Estado; basicamente servia ao porto de Montevidéu, aumentando as ligações econômicas entre a Campanha e o Prata". O pequeno e irregular aproveitamento das ferrovias na vida econômica da sociedade nacional persiste até os dias atuais.

O novo "ciclo de prosperidade", inaugurado na década de trinta, e o "sonho da frota rio-grandense" até a "era dos supermercados", nos anos 50, são assuntos que certamente despertarão o interesse do leitor.

Porto Alegre e seu comércio é um livro de leitura agradável. Importante porque chama a atenção para a necessidade de se estudar com cuidado a História Econômica do Rio Grande do Sul. Neste sentido, importa lembrar Max Weber que dizia que a história econômica não pode ser considerada a história total da cultura. $O$ que sem dúvida é verdadeiro. Mas é verdadeiro, também, que sem ela não se poderá prometer qualquer investigação pro- 
veitosa nos fatos históricos que são essencialmente fatos humanos.

\section{NOTA}

* Professor do Departamento de História da PUCRS. 